\title{
BEBERAPA KELEMAHAN UMUM PROPOSAL PENELITIAN DOSEN UNIVERSITAS PALANGKARAYA
}

Oleh: Triyono ${ }^{1}$

\begin{abstract}
Abstrak
Penelitian merupakan kegiatan ilmiah yang dilakukan melalui prosedur tertentu dengan tujuan untuk memecahkan masalah. Jika penelitian yang akan dilakukan merupakan sebuah tawaran untuk memperoleh dana, kualitas proposal penelitian menjadi sangat penting. Beberapa dosen yang pernah mengajukan proposalnya ke Dikti tetapi ditolak, ada kecenderungan mudah frustasi dan jarang yang mau mengkaji kembali alasan-alasan yang menyebabkan proposalnya ditolak untuk kemudian diperbaiki dan diajukan lagi. Berdasarkan data yang dikaji disimpulkan bahwa kelemahan proposal penelitian dosen Universitas Palangkaraya yang banyak pada: perumusan masalah, manfaat hasil penelitian, tinjauan pustaka, dan aspek metodologi. Padahal dalam format penilaian proposal keempat komponen itu oleh Ditbinlitabmas masing-masing diberi bobot 30, 20, 15, dan $25 \%$.
\end{abstract}

Kata kunci: komponen proposal penelitian, karakteristik penelitian, kelemahan proposal penelitian dosen.

\section{Pendahuluan}

Penelitian-penelitian yang dilakukan oleh dosen di perguruan tinggi pada umumnya lebih ditujukan untuk disajikan dalam seminar yang motivasinya lebih tertuju pada pengakuan profesional melalui angka kredit (credit point) sebagai persyaratan usul kenaikan jabatan dan pangkat. Dengan ditetapkannya perolehan angka kredit sekurang-kurangnya 25\% pada kegiatan penelitian (unsur B) dari keseluruhan angka kredit yang ditentukan untuk usul kenaikan jabatan, seorang dosen senantiasa dituntut melaksanakan penelitian secara rutin, ---di samping kegiatan pendidikan dan pengajaran, pengabdian pada masyarakat, serta unsur penunjang tri dharma perguruan tinggi lainnya--- jika dosen yang bersangkutan menginginkan bisa naik jabatan dan pangkatnya sesuai dengan periode waktu yang ditentukan.

\footnotetext{
${ }^{1}$ Dosen FKIP Universitas Palangkaraya
} 
Namun disayangkan bahwa ketentuan tersebut kadangkala dimanfaatkan oleh sebagian dosen untuk berbuat kurang terpuji dalam melaksanakan penelitian seperti: penelitian yang dilakukan terkesan "asal jadi”, kurang memperhatikan kualitas; bahkan ada dosen yang sekedar "numpang nama" kepada dosen lain. Contoh kasus tersebut jelas bertentangan dengan tujuan ditetapkannya angka kredit yaitu (a) memberikan penghargaan dan pembinaan karir jabatan dosen, (b) peningkatan profesionalisme dosen, (c) diperolehnya produk penelitian bermutu, (d) yang hasilnya dapat dimanfaatkan untuk meningkatkan pendidikan, pengembangan ilmu pengetahuan dan teknologi serta peningkatan kesejahteraan masyarakat.

Khusus penelitian yang dilakukan oleh dosen-dosen di lingkungan Universitas Palangkaraya selama lima tahun terakhir menunjukkan adanya peningkatan yang cukup berarti dalam arti kuantitasnya. Jika pada tahun 1997 terdapat 72 orang dosen yang terlibat dalam kegiatan penelitian, pada tahun 2001 meningkat menjadi 151 orang (Lembaga Penelitian Unpar, 2001). Untuk penelitian dosen yang dananya bersumber dari Dirbinlitabmas, jumlah dosen yang terlibat rata-rata setiap tahunnya berkisar antara 5\% sampai $10 \%$ dari keseluruhan dosen yang terlibat dalam semua jenis penelitian. Data ini mengindikasikan bahwa jumlah proposal penelitian dosen yang diajukan ke Dirbinlitabmas masih relatif kecil jika dibanding dengan jumlah dosen yang ada. Masalahnya adalah mengapa minat dosen Universitas Palangkaraya untuk mengajukan proposal penelitian ke Dirbinlitabmas begitu rendah?

Berkaitan dengan uraian di atas, melalui penelitian ini akan dikaji beberapa kelemahan umum proposal peneltian yang disusun oleh dosen Universitas Palangkaraya. Dengan kajian yang dilakukan secara mendalam dapat diperoleh gambaran mengenai aspek-aspek penelitian yang lemah sehingga dapat dijadikan dasar untuk merancang suatu program pelatihan penelitian yang secara khusus menitikberatkan pada aspek-aspek yang lemah tersebut agar kemampuan dosen dalam menyususn proposal penelitian meningkat. 


\section{Deskripsi Teoretik}

Penelitian di Indonesia dapat dikelompokkan untuk mencapai tujuan-tujuan (1) memenuhi persyaratan dalam memeroleh gelar akademik dan atau sebutan profesional, (2) melanjutkan penelitian bagi para ilmuwan untuk pengembangan ilmu pengetahuan dan teknologi, serta (3) pengambilan keputusan dan kebijakan.

Tujuan yang disebut pertama pada umumnya dilakukan oleh para mahasiswa yang sedang menuntut ilmu di perguruan tinggi untuk memperoleh gelar Sarjana, Magister, dan Doktor yang mempersyaratkan pelaksanaan penelitian dan menuliskan laporannya dalam bentuk skripsi (S-1), tesis (S-2) dan disertasi (S-3). Masalahmasalah yang diteliti oleh para mahasiswa dalam skripsi, tesis atau disertasi umumnya lebih bersifat akademik dan bukan untuk kepentingan praktis untuk pengambilan keputusan. Tujuan penelitian kelompok kedua lebih banyak dilakukan oleh para dosen dan peneliti dengan maksud untuk disajikan dalam forum seminar atau lokakarya. Jika para mahasiswa motivasinya lebih tertuju untuk memenuhi persyaratan dalam memperoleh gelar akademik, bagi para dosen lebih termotivasi pada pengakuan profesional dan kenaikan jabatan. Tujuan penelitian kelompok yang disebut terakhir umumnya merupakan penelitian terapan atau penelitian kebijakan atau penelitian evaluatif yang berkaitan dengan program atau kebijakan pemerintah seperti: studi kelayakan, evaluasi, ujicoba dan kaji tindak (Danin, 2000).

Meskipun tujuan penelitian berbeda-beda sesuai dengan ciri dan sifat suatu penelitian, namun secara metodologik semua jenis penelitian harus dilakukan melalui suatu prosedur yang jelas dan sistematik, menerapkan metode ilmiah dengan tujuan untuk memecahkan masalah (Triyono, 2002). Sebelum pelaksanaan penelitian, biasanya semua jenis penelitian menuntut disusunnya sebuah proposal penelitian sebagai bahan acuan pelaksanaan maupun bahan pertimbangan bagi pemberi dana jika penelitian tadi dibiayai oleh pihak ketiga.

Karena fungsi proposal penelitian sebagai bahan acuan pelaksanaan penelitian, sebuah proposal penelitian harus memuat komponen-komponen pokok 
dari serangkaian langkah penelitian. Suriasumantri (1984) mengidentifikasi langkahlangkah penelitian terdiri dari: merumuskan masalah, mengkaji literatur, merumuskan hipotesis, pengujian hipotesis, dan penarikan kesimpulan; sedangkan Bailey (1978) mengemukakan tahapan penelitian dimulai dari: pemilihan masalah, perumusan hipotesis, penyusunan desain penelitian, pengumpulan dan analisis data, serta penarikan kesimpulan. Langkah-langkah sebuah penelitian secara lengkap ditulis oleh Tuckman (1978a) yang meliputi: identifikasi dan formulasi masalah, kajian literatur, perumusan hipotesis, identifikasi variabel, definisi operasional variabel, manipulasi dan pengendalian variabel, penyusunan desain penelitian, pengembangan alat pengumpulan data, pengumpulan dan analisis data, penarikan kesimpulan, dan penulisan laporan.

Proposal sebuah penelitian yang baik menurut Singarimbun (1984) harus memuat: masalah penelitian, kerangka teori, tujuan penelitian, kegunaan penelitian, hipotesis, metode penelitian, dan rencana pelaksanaan; sedangkan menurut Mercado (1984) komponen-komponen sebuah proposal penelitian meliputi: pendahuluan, masalah, tujuan, kerangka teoretik, kerangka konseptual, hipotesis, dan metodologi. Ary (1982) menyajikan sebuah kerangka penulisan proposal penelitian berisi: pernyataan masalah, tinjauan kepustakaan, hipotesis, metodologi, analisis data, pentingnya penelitian, serta anggaran dan jadwal waktu pelaksanaan.

Perbedaan langkah-langkah yang dijelaskan di atas, tentu saja terkait dengan jenis dan sifat suatu penelitian. Penelitian-penelitian yang bersifat penjajagan sudah barang tentu tidak menuntut adanya suatu hipotesis penelitian, sebab hanya penelitian verifikatif yang memiliki hipotesis. Dalam hubungan ini, Mason dan Bramble (1978) membedakan penelitian ke dalam empat tipe yaitu: penelitian deskriptif, penelitian eksperimen, penelitian historik, dan penelitian evaluatif. Setiap jenis penelitian tersebut selanjutnya dapat dikelompokkan lagi sesuai dengan desain dan sifat penelitiannya. Untuk penelitian eksperimen misalnya, berdasarkan desainnya dapat dibedakan menjadi pre-experimental design, quasi experimental design, dan true experimental design; yang masing-masing memiliki beberapa macam desain 
penelitian yang lebih rinci (Campbell dan Stanley, 1977). Demikian pula penelitianpenelitian yang bersifat korelasional, analisis perbandingan, analisis kecenderungan, analisis dokumen, studi kasus, survei, studi perkembangan, dan studi tindak lanjut digolongkan ke dalam jenis penelitian deskriptif (Ary, 1982).

Karena konteks yang dibahas dalam tulisan ini adalah penelitian dosen, maka format dan sistematika yang digunakan untuk mencermati kelemahan proposal berpedoman pada buku pedoman yang diterbitkan oleh Direktorat Pembinaan Penelitian dan Pengabdian pada Masyarakat (Dirbinlitabmas) Dirjendikti, Depdiknas. Sistematika dan format proposal penelitian dosen muda dan kajian wanita bagi dosen di perguruan tinggi terdiri dari: judul, bidang ilmu, pendahuluan, perumusan masalah, tinjauan pustaka, tujuan penelitian, kontribusi penelitian, metode penelitian, jadwal pelaksanaan, personalia penelitian, dan perkiraaan biaya penelitian (Depdiknas, 2000).

\section{Hasil Penelitian dan Pembahasan}

Ada lima komponen pokok yang dinilai untuk menentukan kelayakan sebuah proposal penelitian diterima atau ditolak untuk diberikan dana yaitu (1) perumusan masalah dengan bobot $30 \%$, manfaat hasil penelitian dengan bobot $20 \%$, tinjauan pustaka dengan bobot $15 \%$, metode penelitian dengan bobot $25 \%$ serta kelayakan penelitian dengan bobot 10\% (Dirbinlitabmas, 2000). Empat kriteria pertama akan dibahas dalam tulisan ini; sedang kriteria terakhir tidak dibahas karena merupakan kriteria yang lebih bersifat administratif.

Setelah mencermati sejumlah proposal penelitian yang disusun oleh dosen Jurusan Budidaya Pertanian Fakultas Pertanian Unpar, dikaitkan dengan kriteria di atas dapat diungkapkan sejumlah kelemahan yang menonjol sebagai berikut.

\section{Perumusan Masalah}

Sebagian besar calon peneliti (baca: dosen BDP) kurang cermat dalam memahami "perumusan masalah" penelitian dan terkecoh dengan "masalah yang 
melatar belakangi” pentingnya penelitian diilakukan. Menurut Tuckman (1978a) ciriciri rumusan masalah penelitian yang baik yaitu (1) mempersoalkan hubungan antara dua atau lebih variabel, (2) dinyatakan secara jelas, tegas dan tidak kabur, (3) dapat diuji secara empirik; artinya memungkinkan pengumpulkan data untuk menjawab masalah yang dirumuskan, dan (4) umumnya dinyatakan dalam bentuk kalimat pertanyaan - tidak suatu keharusan.

Dengan kriteria tersebut, dari sejumlah proposal yang dikaji disimpulkan bahwa rumusan masalah dalam proposal penelitian dosen Jurusan BDP fakultas Pertanian Unpar masih lemah. Indikasinya dapat disimak contoh-contoh berikut.

Kasus-1:

1. Tanah berupa podsolik merah kuning dengan tingkat kesuburan yang rendah sehingga sulit dikembangkan sebagai lahan pertanian.

2. Penggunaan lahan belum optimal karena banyaknya sisa-sisa pohon bekas tebangan yang belum dibersihkan.

3. Masyarakat masih belum melakukan budidaya pertanian dengan acuan pola tanam yang benar dan belum menerapkan teknologi tepat guna.

4. Pembinaan terhadap petani masih terbatas.

Kasus-2:

1. Tanah gambut umumnya mempunyai reaksi masam sampai sangat masam, sehingga tidak menunjang ketersediaan unsur hara untuk pertumbuhan tanaman budidaya.

2. Usaha untuk memperbaiki tingkat kesuburan tanah pada umumnya dapat dilakukan dengan cara pemberian kapur, pupuk anorganik dan organik, serta pengembangan varietas yang toleran terhadap lingkungan.

3. Untuk mencapai sasaran tersebut di atas, penambahan bahan organik dan penggunaan varietas yang toleran terhadap lingkungan perlu dilakukan.

Kasus-3:

1. Dalam pengendalian hama dan penyakit tanaman, sering mengalami beberapa hal yang menyebabkan efek bagi tanaman dan juga hama itu sendiri yang pada 
akhirnya akan memberikan pengaruh bagi pertumbuhan dan hasil tanaman yang dibudidayakan.

1. Penggunaan insektisida dapat mengganggu kelangsungan ekosistem baik yang beresidu maupun hanya sebentar, namun efek residunya sangat berpengaruh bagi tanah itu sendiri.

2. Untuk mengatasi hal tersebut maka digunakan rimpang jahe yang banyak dihasilkan oleh masyarakat sekitar, karena penggunaan rimpang jahe sebagai insektisida yang ramah lingkungan sangat menguntungkan dalam teknik budidaya dan pengandalian hama dan penyakit tanaman.

Ketiga contoh rumusan masalah di atas bukan merupakan rumusan masalah yang akan diteliti, akan tetapi merupakan hal-hal yang melatar belakangi mengapa penelitian yang disusun proposalnya perlu dilakukan. Contoh-4 dan contoh-5 berikut merupakan rumusan masalah penelitian yang benar.

Kasus-4:

1. Bagaimana tingkat preferensi kelinci terhadap berbagai alternatif pakan.

2. Sejauh mana pakan yang diberikan disukai oleh kelinci dan berpengaruh terhadap waktu yang dibutuhkan untuk menghabiskan pakan tersebut, rataan konsumsi pakan, pertambahan bobot badan, dan bobot badan akhir kelinci.

Kasus-5:

1. Apakah terdapat pengaruh pemberian pupuk TSP pada dosis yang berbeda terhadap pertumbuhan dan hasil kacang tanah pada lahan kering?

2. Apakah terdapat pengaruh pemberian mulsa alang-alang pada tingkat yang berbeda terhadap pertumbuhan dan hasil kacang tanah pada lahan kering?

3. Apakah terdapat interaksi pengaruh pemberian pupuk TSP dan mulsa alang-alang pada dosis yang berbeda terhadap pertumbuhan dan hasil kacang tanah pada lahan kering?

4. Pada kombinasi dosis mana pupuk TSP dan mulsa alang-alang yang memberikan pertumbuhan dan hasil kacang tanah maksimal pada lahan kering? 
Pada contoh-4 dan contoh-5, calon peneliti tahu benar apa yang akan dijawab melalui penelitiannnya, dan tidak bercerita tentang hal-hal yang melatar belakangi pentingnya penelitian dilakukan.

\section{Manfaat Hasil Penelitian}

Manfaat atau kontribusi atau sumbangan penelitian mengacu pada manfaat (siapa dan untuk apa) hasil penelitian dapat dimanfaatkan. Hal ini berarti menunjuk pada faktor eksternal untuk dapat mengambil manfaat dari hasil penelitian yang disusun proposalnya (untuk orang lain, bukan peneliti). Lain halnya dengan "tujuan penelitian" yang harus berhubungan langsung dengan "masalah penelitian".

Manfaat hasil penelitian dapat dikaitkan dengan seberapa jauh hasil penelitian itu mampu memberikan sumbangan untuk (1) pengembangan ilmu pengetahuan dan teknologi, atau (2) memecahkan masalah pembangunan, atau bisa pula untuk (3) pengembangan kelembagaan. Perhatikan beberapa contoh rumusan "manfaat penelitian” dari proposal penelitin dosen jurusan BDP berikut.

Kasus-6:

Adapun manfaat dari penelitian ini adalah untuk mengatasi kendala dalam budidaya kacang tanah di lahan kering yaitu salah satunya dengan cara mengkombinasikan penggunaan mulsa dan pupuk TSP.

Kasus-7:

Manfaat dari hasil penelitian ini diharapkan sebagai bahan informasi dalam rangka mengembangkan dan meningkatkan hasil tanaman jagung semi atau baby corn pada tanah gambut pedalaman.

Pada kasus-6 dan kasus-7 tidak dijelaskan siapa yang dapat memperoleh manfaat dan dalam bentuk apa. Bandingkan dengan contoh-8 berikut ini. Kasus-8:

Hasil penelitian ini diharapkan dapat memberi manfaat dan kontribusi bagi para petani hortikultura di kelurahan Kalampangan dalam hal (a) menambah pengetahuan tentang cara-cara pengapuran yang benar untuk meningkatkan 
kesuburan tanah gambut, (b) meningkatkan keterampilan dalam membuat porasi dari gulma padat dan air untuk dimanfaatkan sebagai pengganti pupuk kompos, (c) menyediakan pilihan komposisi/campuran antara porasi dan kapur yang memberikan hasil terbaik bagi tanaman cabe, serta (d) memberikan contoh dalam bentuk demofarm penanaman cabe secara benar sehingga diperoleh hasil yang maksimum.

Di samping itu, hasil penelitian ini juga bermanfaat bagi para penyuluh pertanian lapangan (PPL) dalam merencanakan dan menyusun materi penyuluhan kepada petani binaannya tentang cara meningkatkan kesuburan tanah dan budidaya tanaman cabe pada tanah gambut pedalaman. Hasil penelitian ini juga berguna bagi masyarakat dalam upaya meningkatkan kualitas lingkungan melalui pemanfaatan gulma darat dan air yang selama ini menggangggu tanaman yang dibudidayakan.

\section{Tinjauan Pustaka}

Komponen lain yang dievaluasi dalam proposal dilihat dari tinjauan pustaka yang indikator-indikatornya meliputi: relevansinya dengan masalah yang diteliti, kemutakhiran sumber, serta cara pengorganisasian dalam penyajian dalam arti apakah dikemas secara runtut berdasarkan alur perpikir logis.

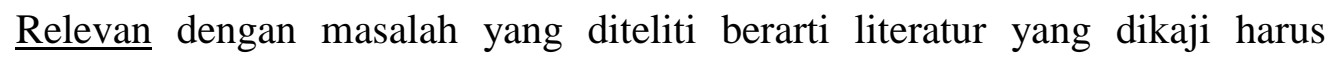
mengarah pada pemecahan masalah (kuncinya: semua variabel yang diteliti harus dibahas dalam kajian pustaka). Kemutakhiran menunjuk pada bahan yang dirujuk diambil dari sumber-sumber yang up to date (tahun penerbitan relatif baru dan yang lebih penting lagi adalah jurnal penelitian).

Dari sejumlah proposal penelitian dosen Universitas palangkaraya yang dicermati dalam rangka menyiapkan makalah ini dapat ditemukan kelemahan yang menonjol yaitu tidak tersaji rumusan "hipotesis", padahal hampir semua penelitian yang dirancang merupakan penelitian verifikatif (menguji hipotesis). Dengan demikian, kajian pustaka yang dibahas terkesan hanya sebagai "pajangan” semata.

Mestinya, jika dalam suatu proposal rumusan masalahnya sebagaimana dinyatakan dalam kasus-5, maka rumusan hipotesisnya adalah: 
Berkaitan dengan hal di atas, kajian pustaka dalam proposal setidak-tidaknya harus membahas tentang (1) botani kacang tanah, (2) pupuk TSP, (3) mulsa, dan (4) lahan kering. Kemudian pada bagian akhir kajian pustaka dinyatakan bahwa berdasarkan pembahasan teori, hasil penelitian, dan alasan-alasan serta justifikasi peneliti menyusun hipotesis berupa dugaan jawaban atas rumusan masalah yang disimpulan secara deduktif dari teori yang dikaji, misalnya sebagai berikut.

Kasus-9:

1. Pemberian pupuk TSP pada dosis yang berbeda berpengaruh terhadap pertumbuhan dan hasil kacang tanah pada lahan kering.

2. Pemberian mulsa dari alang-alang pada dosis yang berbeda memberikan pengaruh terhadap pertumbuhan dan hasil kacang tanah pada lahan kering.

3. Ada interaksi pengaruh pemberian pupuk TSP dan mulsa alang-alang terhadap pertumbuhan dan hasil kacang tanah pada lahan kering.

Apakah dugaan (hipotesis) yang diajukan oleh peneliti tersebut benar (diterima) atau salah (ditolak) akan diuji di lapangan dengan cara melakukan percobaan. Setelah percobaan lapang dilakukan, parameter data diukur, dengan bantuan statistik dibuatlah kesimpulan secara induktif. Kesimpulan itu mungkin menerima atau menolak hipotesis yang dirumuskan. Hipotesis dinyatakan diterima jika berdasarkan data di lapangan mendukung; sebaliknaya hipotesis ditolak jika data di lapangan tidak mendukung.

Namun perlu disadari bahwa statistik itu didasarkan pada teori peluang (probability), artinya kebenaran statistik adalah kebenaran yang bersifat probabilistik maka digunakan istilah "level of signifinace" atau taraf signifikansi (dosen jurusan BDP menggunakan istilah taraf nyata) dan dinyatakan dengan simbol alpha $(\alpha)$. Angka ini sebenarnya merupakan peluang terjadinya kesalahan tipe pertama (type-1 error) yaitu kesalahan dalam hal menolak Ho yang benar. Bilangan $(1-\alpha)$ disebut sebagai "level of confidence" atau taraf keyakinan/ kepercayaan. Peluang terjadinya kesalahan tipe -2 (type-2 error) dilambangkan dengan $\beta$ (beta) yakni kesalahan 
dalam menerima Ho yang salah. Bilangan $(1-\beta)$ dinamakan power of test dari alat analisis (misalnya Uji-F) yang menyatakan sampai seberapa besar kecermatan alat statistik yang digunakan.

Oleh karena itu, untuk tinjauan pustaka mestinya terdiri dari tiga pembahasan yaitu (1) deskripsi teoretis, (2) kerangka berpikir, dan (3) rumusan hipotesis. Deskripsi teoretis mengungkapkan variabel-variabel yang akan diteliti termasuk hasil-hasil penelitian relevan; kerangka berpikir merupakan penjelasan atau justifikasi peneliti yang mengarahkan pada rumusan hipotesis; sedangkan rumusan hipotesis yang merupakan klimaks (kesimpulan) deduksi dari teori yang dikaji melalui penjelasan, argumentasi dan justifikasi peneliti.

\section{Aspek Metodologi}

Aspek metodologi merupakan salah satu komponen yang harus jelas dalam suatu proposal penelitian. Aspek metodologi harus dapat menggambarkan bagaimana penelitian akan dilaksanakan, termasuk tahapan-tahapannya sampai pada bagaimana data dikumpulkan dengan alat ukur apa --tingkat ketelitian alat-dan bagaimana kesimpulan induktif akan diambil. Jika digunakan alat statistik untuk menguji hipotesis juga harus dinyatakan pada taraf signifikansi berapa untuk menerima atau menolak hipotesis yang diajukan.

Aspek metodologi setidak-tidaknya memuat: kapan dan di mana penelitian akan dilakukan, aspek dan subjek yang diteliti, metode yang akan ditempuh, alat dan bahan yang diperlukan,--kegunaan tiap alat dan bahan. Untuk penelitian survei juga harus jelas siapa sampelnya serta bagaimana cara memilih sampel tersebut, sampai pada teknik pengumpulan data dan analisis data untuk mengambil kesimpulan.

Kelemahan aspek metodologi yang dijumpai dalam proposal penelitian dosen Universitas Palangkaraya umumnya terletak pada tidak dijelaskan kegunaan alat dan bahan penelitian. Hampir semua proposal yang dikaji hanya menyebutkan alat dan bahan penelitiannya saja. 
Dengan demikian, antara rumusan masalah, tujuan penelitian, hipotesis, dan kesimpulan penelitian harus ada benang yang menghubungkan secara jelas. Hal ini disebabkan proses penelitian merupakan serangkaian langkah sistematik dengan tujuan memecahkan masalah.

\section{Daftar Pustaka}

Ary, Donald. et al. (1982). Pengantar Penelitian dalam Pendidikan. terjemahan Arief Furchan. Surabaya: Usaha Nasional.

Bailey, Kenneth D. (1978). Methods of Social Research. New York: The Free Press.

Campbell, D.T. and Stanley, J. (1977). Experimental and Quasi Experimental Designs for Research. Chicago: Rand McNally and Co.

Danin, Sudarwan. (2000). Pengantar Studi Penelitian Kebijakan. Jakarta: Bumi Aksara.

Departemen Pendidikan Nasional. (2000). Pedoman Pelaksanaan Penelitian dan Pengabdian pada Masyarakat oleh Perguruan Tinggi. Jakarta: Dirbinltabmas, Dirjendikti, Depdiknas.

Mason, E.J. and Bramble, W.J. (1978). Understanding and Conducting Research. New York: McGraw-Hill.

Mercado, Cesar M. (1984). Pedoman Penyusunan Usul Penelitian. Surakarta: Hapsara.

Singarimbun, Masri. (1984). Pedoman Praktis Membuat Usulan Penelitian. Jakarta: Ghalia Indonesia.

Suriasumantri, Jujun. (1984). Ilmu dalam Perspektif: Sebuah Kumpulan Karangan tentang Hakekat Ilmu. Jakarta: Yayasan Obor - Leknas LIPI.

Tuckman, Bruce W. (1978a). Conducting Educational Research. San Diego: Harcourt Brace Jovanovich, Publishers.

Triyono. (2002). “Konsep Dasar Penelitian” Makalah Pelatihan Penelitian Tingkat Dasar Bagi Peneliti Balitbangda Propinsi Kalimantan Tengah. Palangkaraya, 29 s/d 31 Januari 2002. 